\title{
Adaptability of the workforce in Europe - changing skills in the digital era*
}

\author{
Maja Jandrić ${ }^{1}$ Saša Ranđelović ${ }^{2}$
}

\begin{abstract}
Digital technologies make significant impact on labor market, primarily by complementing or by substituting workers. This has triggered a change in the set of skills that are required from workers, by putting stronger focus on problemsolving skills, creativity, socioemotional skills, functional literacy and technical skills related to the use of digital technologies. The effects of digitalization on the labor market and economic performances of a particular country in the future depend on the workforce adaptability, industrial and occupational structure, the skills mix, organization of work and current state of digitalization. The aim of this paper is to evaluate the degree of workforce skills adaptability in 30 European countries, using the OECD data on achievement in reading, math and science, as well as the data on digital competencies, inclusion in lifelong learning and subjective perception on ability to find a new job. Our results suggest positive relationship between adaptability and PISA results. Using the principal component analysis, cluster analysis and LCCA (latent class cluster analysis), we find that European countries can be grouped into three clusters, in terms of adaptability: high performing (North and Western Europe), medium performing (Central Europe and Baltics) and low performing (South and South-eastern Europe). For some countries, low levels of adaptability of the workforce can pose an important obstacle for future growth and development.
\end{abstract}

Key words: labor market, digitalization, lifelong learning, digital competencies, Principal Component Analysis, Latent Class Cluster Analysis

JEL classification: J24, J21, J62

\footnotetext{
* Received: 02-05-2018; accepted: 27-11-2018

1 Assistant Professor, University of Belgrade, Faculty of Economics, Kamenička 6, 11000 Belgrade, Serbia. Scientific affiliation: economic theory and analysis - macroeconomics. Phone:+381113021184.E-mail: maja@ekof.bg.ac.rs. Website: http://www.ekof.bg.ac.rs/majajandric-phd/? lang=en (corresponding author).

2 Associate Professor, University of Belgrade, Faculty of Economics, Kamenička 6, 11000 Belgrade, Serbia. Scientific affiliation: economic theory and analysis - macroeconomics. Phone: +381113021183.E-mail: randjelovic@ekof.bg.ac.rs.Website: http://www.ekof.bg.ac. rs/sasa-randjelovic-phd/?lang=en.
} 


\section{Introduction}

Contemporary labor market is fundamentally shaped by demographic trends, accelerating globalization and deepening technological progress. Developed countries of OECD are facing population aging, the demographic forecasts suggesting considerable further decline of the working-age population in these countries. Globalization promotes integration of goods and services markets and paves the way for smoother technological dissemination. These developments have several opposing effects on the labor market. In one hand, lower transaction costs tend to promote development of high value-added services sector, which is sustained by the demand from foreign markets. In the other hand, globalization creates incentives for offshoring, services outsourcing and increasing exposure to competition of manufacturing labor force in developed countries, to their lower-cost counterparts in developing countries. Technological progress leads to automatization of tasks, traditionally performed by humans. In the last couple of decades this was mostly the case with the routine tasks, while nowadays, with emerging of Artificial Intelligence, Big Data, Internet and development of computing power, there is a trend of automation of more sophisticated tasks and activities as well. Technological advancement is expected to affect labor market both in developed and in developing economies. As the developed countries have higher labor costs, they are perceived as more incentivized to aim at replacing humans with machines in business operations. However, that risk is also present in developing economies, as full automation of business operations creates incentives for companies to reallocate manufacturing back closer to their main markets (developed countries). This hypothesis is supported by the data on the manufacturing employment data in developing economies, which are facing decline in share of manufacturing employment in the early stage of industrialization, thus creating "middle income trap" risk (Rodrik, 2016).

This paper is aimed at filling the gap in the empirical literature on the impact of digitalization on labor market in Europe, by providing the empirical analysis of the level of workforce adaptability and the quality of skills-mix. In that respect, we use the Eurostat data on digital competences, inclusion in lifelong learning, and subjective perception of competitiveness at the labor market, as well the data on PISA results in science, mathematics and reading.

The main hypothesis is that numerous indicators can be grouped into smaller number of dimensions, which describe key characteristics of a country's workforce adaptability and the quality of skill mix. Besides that, our hypothesis is that although there is a large variation across Europe, these countries can be pooled into several clusters with similar characteristics.

Data suggest positive relationship between the adaptability and PISA results in Europe. By means of the principal component analysis and cluster analysis, we find 
that European countries can be grouped into three clusters - North and Western Europe, which are high performing, Central Europe and Baltics which are medium performing and South and South-eastern Europe which are low performing. The results could be used as an information base for reshuffling policies, particularly in terms of modernization of education, promotion of entrepreneurship, redesign of active labor market policies and investments in innovations in these countries.

The rest of the paper is structured as follows. In Section 2 we provide brief literature review. Section 3 presents data and methodology. Section 4 provides results of the principal component analysis, cluster analysis and LCCA, Section 5 deals with the discussion of the results, while Section 6 concludes.

\section{Literature review}

Automatization, driven by development of technologies, may have a severe impact on the labor market size, structure and features in the future. It is expected that in the future, role of workers would be transformed from managing to monitoring of the machines. At the same time, the key parameters of competitiveness of workers at the labor market will be related to interdisciplinary skills and creativity, instead of specialization. In terms of the form, life-time jobs with employment contract and strictly defined working hours are expected to be increasingly replaced by flexible working arrangements. Technological innovations are expected to influence the size of labor market as well. Empirical studies suggest that 5\% of occupations will be questioned due to full automatization, while for almost two thirds of occupations, there is a risk of at least partial automatization (Manyika et al. 2017). Risk of automatization will be particularly high in transportation, logistics, administration, manufacturing and trade sectors (Frey and Osborne, 2017). World Bank (2016) study shows that the share of jobs potentially jeopardized by new technologies in the Western Balkans, range from $62 \%$ in Bulgaria to over $68 \%$ in Macedonia and Romania ${ }^{3}$.

In this paper, we refer to digitalization as a process of broadening application of the ICT (information and communications technology) in doing business. Although there are various definitions, according to Sheperd (2004) the digital era is characterized by technology which increases the speed and breadth of knowledge turnover within the economy and society. Degryse (2016) summarizes the key impacts of digitalization on the labor market: job creation/ job destruction, job change (human/intelligent machine interface, new forms of management) and job shift (digital platforms, crowd sourcing, sharing economy).

Digitalization is also expected to put stronger emphasis on the new skills, such as problem- solving, creativity and communications. According to Cunningham

\footnotetext{
3 These values correspond to estimates that are not adjusted to the speed of adopting new technology.
} 
and Villasenor (2016) the three most wanted skills by employers would be socioemotional (50\%), cognitive (29\%) and technical (15.9\%). Although the mentioned study is an overview of the employers needs, not necessarily being a consequence of digitalization, it may also suggest that changes in technology require new skills and adequate capability of the labor force to adapt. This is also emphasized in the World Development Report 2019, which argues that "in the digital era, advances in technology call for new skills seemingly overnight". Further to the World Development Report 2019, the changing nature of work, induced by automatization and digitalization, triggers need for development of a combination of general and technical skills, with an increasing importance of a higher-order general skills, which is different from the primary focus on narrower technical skills, that was a prevailing paradigm in the past.

Considering the impact technological advancement and digitalization are expected to make on labor market, the position of an individual at that market in the future will be substantially shaped by degree of adaptability, i.e. individual's employability is expected to be strongly linked to her/his adaptability. Broader concept of labor market adaptability refers to the ability of the labor market to provide protection against uninsurable labor market risk, to provide training in order to ensure that labor skills continuously match demand as economic development and technological advance take place and as the international division of labor evolves, to preserve an efficient degree of geographical mobility and to mobilize labor supply and ensure a sizeable labor force (Boeri et al, 2002). Tinsley and Monastiriotis (2007) define labor market flexibility according to three broad domains: production function flexibility, labor costs flexibility and supply-side flexibility. Supply-side flexibility covers several aspects, both in terms of quantity and in terms of the quality of the labor force, as well as in terms of the labor mobility. In this paper, we focus mainly on the "quality" element, which relates to knowledge and skills. By the term "adaptability", we refer to the potential of workers to adapt their knowledge and skills to changing labor market needs, which are driven predominantly by technological change, but also by other characteristics of the labor market in the $21^{\text {st }}$ century (i.e. globalization, demographic changes etc.)

Skills mismatch is an important dimension of labor market disequilibria (Bejaković and Mrnjavac, 2014) and is proven to have a significant impact on future labor market equilibrium (Dimian et al., 2017). Technology is changing the skills being rewarded in the labor market, by putting stronger emphasis on skills that cannot be replaced by robots (World Development Report, 2018), such as general cognitive skills and socio-behavioral skills - workers with these skills are considered to be more adaptable in labor markets. Increasing importance of digital skills at the labor market is widely recognized in the literature (see Eshet-Alkalai, 2004). In this paper, we mainly focus on digital competences, life-long learning, and PISA results as a measure of general cognitive skills, which are also identified as some of the key competences in the knowledge society (European Commission, 2009). 
Hanushek and Woessmann (2008) find strong evidence that the cognitive skills of the population, rather than mere school attainment, affect economic performances. Instead of school attainment, they focus on the outcomes (i.e. knowledge and skills), that may be the result of schooling process, but also of other sources of learning, because school completion may not necessarily reflect the level of cognitive skills. These skills are measured by international tests, among others PISA tests. For these reasons, we rely on internationally comparable data from the students' achievement tests, rather than on the number of persons engaged in higher levels of education or number of persons with tertiary education degree. In contrast to Hanushek and Woessmann (2008), who measure cognitive skills as a simple average of mathematics and science scores over several international tests, we use all three aspects of PISA testing: mathematics, science and reading.

\section{Methodology}

The Principal Component Analysis (PCA) is used for assessment of the relative position of 30 European countries according to the levels of the workforce skills adaptability to the rapid technological changes. The aim of the PCA is to sum information from larger group of variables into limited group of factors that cannot be measured directly (Aaker et al., 2008). While transforming original variables into new uncorrelated variables named factors, it is crucial to keep as much of the original variability as possible. Since the factors cannot be measured directly, they are revealed on the basis of the initial variables (Aaker et al., 2008) and their interpretation is based on their correlations with original variables. One of the main strengths of this method is that it can summarize a set of individual indicators while preserving the maximum possible proportion of the total variation in the original data set. According to OECD, this method is convenient for cross country comparisons, since the largest factor loadings are assigned to the individual indicators that have the largest variation across countries, which is a desirable property for cross-country comparisons, as individual indicators that are similar across countries are of little interest and cannot explain differences in performance (OECD, 2008).

To conduct the PCA and cluster analysis, the following data on participation in lifelong learning, subjective perception of employability, the Eurostat data on digital competences (2015) and achievement in reading, mathematics and science from PISA testing (2012) in 30 European countries have been used: ${ }^{4}$

\footnotetext{
4 Austria, Belgium, Bulgaria, Croatia, Cyprus, Czech Republic, Denmark, Estonia, Finland, France, Germany, Greece, Hungary, Ireland, Italy, Latvia, Lithuania, Luxembourg, Macedonia (FYROM), Malta, the Netherlands, Poland, Portugal, Romania, Serbia, Slovak Republic, Slovenia, Spain, Sweden and the UK.
} 
i. Lifelong learning - participation rate in education and training (last 4 weeks), age $25-64$;

ii. Information skills - Percentage of all individuals who have above basic information skills in the digital competencies framework;

iii. Communication skills - Percentage of all individuals who have above basic communication skills in the digital competencies framework;

iv. Problem-solving skills - Percentage of all individuals who have above basic problem-solving skills in the digital competencies framework;

v. Software skills - Percentage of all individuals who have above basic software skills in the digital competencies framework;

vi. Competitiveness perception - Percentage of the employed persons who find it easy to find a job of similar salary (European Working Conditions Survey);

vii. Underachieving in reading - Percentage of underachieving 15-year-old students in reading (PISA);

viii. Underachieving in mathematics - Percentage of underachieving 15-year-old students in mathematics (PISA);

ix. Underachieving in science - Percentage of underachieving 15-year-old students in science (PISA) ${ }^{5}$.

Absence of continual improvement of skills and knowledge through lifelong learning (variable $i$ ) can result in uncompetitive level of skills needed to face challenges initiated by technological improvement and digitalization. Digital skills indicators $(i i-v)$ are indicators that, in line with Eurostat methodology, can be considered as proxy of the digital competences and skills of individuals. These indicators are based on selected activities related to internet or software use performed by individuals aged 16-74 in four specific areas (information, communication, problem solving, software skills). It is assumed that individuals having performed certain activities have the corresponding skills. Digital competence skills framework is disclosed in Appendix (Table A1). Variable vi describes perception of the employed persons of her/his competitiveness at the labor market, which may be interpreted as a proxy for subjective perception of labor market (in)security and employability. Variables vii-ix represent general functional knowledge and relates to PISA results in reading, mathematics and science.

On the basis of these original variables, key skill groups (factors) have been determined, based on which the cross-country comparison in terms of each obtained factor is conducted. In the next step, in order to detect similar country groups, the

$\overline{5}$ Data from 2012 was used due to absence of 2015 data for Serbia. Only for Macedonia and Malta data from 2015 have been used, since there is no available data for 2012. 
cluster analysis is performed. To check the robustness of the cluster groups, several clustering methods, as well as latent class analysis were performed (Latent Class Cluster Models).

\section{Empirical data and analysis}

Prior to analysis, it has been evaluated whether the PCA method is suitable for identification of factors. In that respect, the Bartlett's test of sphericity and the Kaiser-Meyer-Olkin measure of sampling adequacy have been used. Both the Bartlett's test and the Kaiser-Meyer-Olkin test have indicated that the PCA method is appropriate (see the test statistics in Appendix Table A2). Regarding the ratio of number of observed countries and number of original variables, our starting point was the rule that sets less strict limitations and states that ratio of 3:1 or higher ensures stable solutions in the PCA (Peres-Neto et al., 2003; Grossman et al. 1991).

\subsection{Principal component analysis}

As the PCA method is assessed as appropriate, the next step is to determine the number of components. This is commonly done by inspection of the correlation matrix eigenvalues: the Cattell scree test and the Kaiser rule. According to the scree test, only those components above the point of inflection on a plot of eigenvalues ordered by diminishing size should be retained. Kaiser rule recommends that only eigenvalues at least equal to one are retained. Both the scree plot test and Kaiser rule point to conclusion that two factors should be retained in the analysis (Table 1). The initial eigenvalues statistics also suggests that two detected factors explain $85.43 \%$ of total variability, which is satisfactory.

Table 1: Total variance explained

\begin{tabular}{|c|c|c|c|c|c|c|c|c|c|}
\hline \multicolumn{10}{|c|}{ Total Variance Explained } \\
\hline \multirow{2}{*}{$\begin{array}{c}\text { Compo- } \\
\text { nent }\end{array}$} & \multicolumn{3}{|c|}{ Initial Eigenvalues } & \multicolumn{2}{c|}{$\begin{array}{c}\text { Extraction Sums of Squared } \\
\text { Loadings }\end{array}$} & \multicolumn{3}{|c|}{$\begin{array}{c}\text { Rotation Sums of Squared } \\
\text { Loadings }\end{array}$} \\
\cline { 2 - 11 } & Total & $\begin{array}{c}\% \text { of } \\
\text { Variance }\end{array}$ & $\begin{array}{c}\text { Cumu- } \\
\text { lative \% }\end{array}$ & Total & $\begin{array}{c}\text { \% of } \\
\text { Variance }\end{array}$ & $\begin{array}{c}\text { Cumu- } \\
\text { lative \% }\end{array}$ & Total & $\begin{array}{c}\% \text { of } \\
\text { Variance }\end{array}$ & $\begin{array}{c}\text { Cumu- } \\
\text { lative \% }\end{array}$ \\
\hline 1 & 5.886 & 65.402 & 65.402 & 5.886 & 65.402 & 65.402 & 4.455 & 49.496 & 49.496 \\
\hline 2 & 1.802 & 20.027 & 85.429 & 1.802 & 20.027 & 85.429 & 3.234 & 35.933 & 85.429 \\
\hline 3 & .553 & 6.146 & 91.575 & & & & & & \\
\hline 4 & .399 & 4.431 & 96.006 & & & & & & \\
\hline 5 & .202 & 2.248 & 98.253 & & & & & & \\
\hline 6 & .075 & .835 & 99.088 & & & & & & \\
\hline 7 & .034 & .377 & 99.465 & & & & & & \\
\hline
\end{tabular}


Maja Jandrić, Saša Ranđelović • Adaptability of the workforce in Europe - changing skills... Zb. rad. Ekon. fak. Rij. • $2018 \cdot$ vol. $36 \cdot$ no. $2 \cdot 757-776$

\begin{tabular}{|c|c|c|c|c|c|c|c|c|c|}
\hline \multicolumn{10}{|c|}{ Total Variance Explained } \\
\hline \multirow{2}{*}{$\begin{array}{c}\text { Compo- } \\
\text { nent }\end{array}$} & \multicolumn{3}{|c|}{ Initial Eigenvalues } & \multicolumn{3}{|c|}{$\begin{array}{c}\text { Extraction Sums of Squared } \\
\text { Loadings }\end{array}$} & \multicolumn{3}{|c|}{$\begin{array}{c}\text { Rotation Sums of Squared } \\
\text { Loadings }\end{array}$} \\
\hline & Total & $\begin{array}{c}\text { \% of } \\
\text { Variance }\end{array}$ & $\begin{array}{l}\text { Cumu- } \\
\text { lative \% }\end{array}$ & Total & $\begin{array}{c}\% \text { of } \\
\text { Variance }\end{array}$ & $\begin{array}{l}\text { Cumu- } \\
\text { lative \% }\end{array}$ & Total & $\begin{array}{c}\% \text { of } \\
\text { Variance }\end{array}$ & $\begin{array}{l}\text { Cumu- } \\
\text { lative \% }\end{array}$ \\
\hline 8 & .028 & .310 & 99.776 & & & & & & \\
\hline 9 & .020 & .224 & 100.000 & & & & & & \\
\hline
\end{tabular}

Source: Authors' calculations

In order to enhance the interpretability of the results and to obtain a clear pattern of loadings, it is standard practice to perform rotation. As it is plausible to assume that there is some correlation between the two factors, the oblique rotation method (Direct Oblimin) is selected as more adequate. However, both Varimax and Direct Oblimin rotation give similar results and interpretation of the factors doesn 't change (Table 2).

The correlation coefficients between factors and original variables are called factor loadings. Table 2. presents the factor loadings for the observed indicators. Factor loadings show how each of original variables correlates with every factor, while higher values mean a closer relationship. This information is then creatively used to identify and name the unobservable factors (Aaker et al., 2008).

The results indicate identification of two factors and suggest a few conclusions. The first factor can be interpreted as adaptability/employability ${ }^{6}$ since it relates to high level of all aspects of digital skills, high participation in lifelong learning programs and perception that the probability for finding a new job in the next 6 months is high. This is indicated by the values of factor loadings of 0.760 and more in the Table 2, which show that these variables load highly on Factor 1. This factor explains $65.4 \%$ of the total variability (Table 1). The second factor may stand for PISA success since all three relevant variables (PISA results in reading, mathematics and science) $)^{7}$ load highly on factor 2 (Table 2). This factor explains additional $20.03 \%$ of the variability.

6 The name of this factor was influenced by the variables that load highly on the Factor 1. However, it is necessary to note that adaptability and employability are still different concepts, since employability cannot be defined solely in terms of individual (or labour force) characteristics, as it also depends on the general economic conditions (Brown et al., 2003).

7 Shares of underachieving 15-year-old students in PISA testing were given with the minus sign in order to facilitate interpretation of the factor (so that the higher values mean the better results). 
Maja Jandrić, Saša Ranđelović • Adaptability of the workforce in Europe - changing skills...

Table 2: PCA results

\begin{tabular}{|c|c|c|c|c|}
\hline \multicolumn{3}{|c|}{ Rotated Component Matrix $^{\mathrm{a}}$} & \multirow{2}{*}{\multicolumn{2}{|c|}{$\frac{\text { Pattern Matrix }^{\mathrm{a}}}{\text { Component }}$}} \\
\hline & \multicolumn{2}{|c|}{ Component } & & \\
\hline & 1 & 2 & 1 & 2 \\
\hline Lifelong learning & .818 & & .835 & \\
\hline Information skills & .872 & .383 & .857 & \\
\hline Communication skills & .900 & & .971 & \\
\hline Problem-solving skills & .892 & .415 & .871 & \\
\hline Software skills & .814 & .325 & .807 & \\
\hline Competitiveness perception & .760 & & .796 & \\
\hline Underachieving in reading & & .967 & & .995 \\
\hline Underachieving in mathematics & .324 & .929 & & .918 \\
\hline Underachieving in science & & .972 & & .998 \\
\hline \multicolumn{5}{|c|}{$\begin{array}{l}\text { Extraction Method: Principal Component Analysis. } \\
\text { Rotation Method: Varimax with Kaiser Normalization. }{ }^{\text {a }}\end{array}$} \\
\hline \multicolumn{3}{|c|}{ a. Rotation converged in 3 iterations. } & \multicolumn{2}{|c|}{$\begin{array}{l}\text { a. Rotation converged in } 4 \\
\text { iterations. }\end{array}$} \\
\hline
\end{tabular}

Source: Authors' calculations

\subsection{Cluster analysis}

In the next step countries are grouped in accordance to cluster analysis results. Generally, cluster analysis encompasses a number of different al gorithms and methods for grouping similar observations into respective categories based on a set of variables that describe the key features of the observations. Optimal number of clusters (3) was determined by hierarchical cluster analysis, using squared Euclidean distance as a measure of distance and various cluster methods (Ward's method, Between groups method and Centroid method), which all led to the same conclusion about the number of clusters. Based on the previously defined number of clusters, a non-hierarchical K-means clustering was performed. This method, opposite to hierarchical methods, allows subjects to move from one cluster to another, and it is generally more reliable in comparison to hierarchical methods (Aaker et al., 2008.). However, K-means clustering can be very sensitive to the choice of the initial cluster centers. In this case, the same results have been obtained without any prior specification of cluster centers and with predefined cluster centers obtained from the initial hierarchical cluster analysis. 
Figure 1: Distribution of countries by adaptability/employability and PISA success

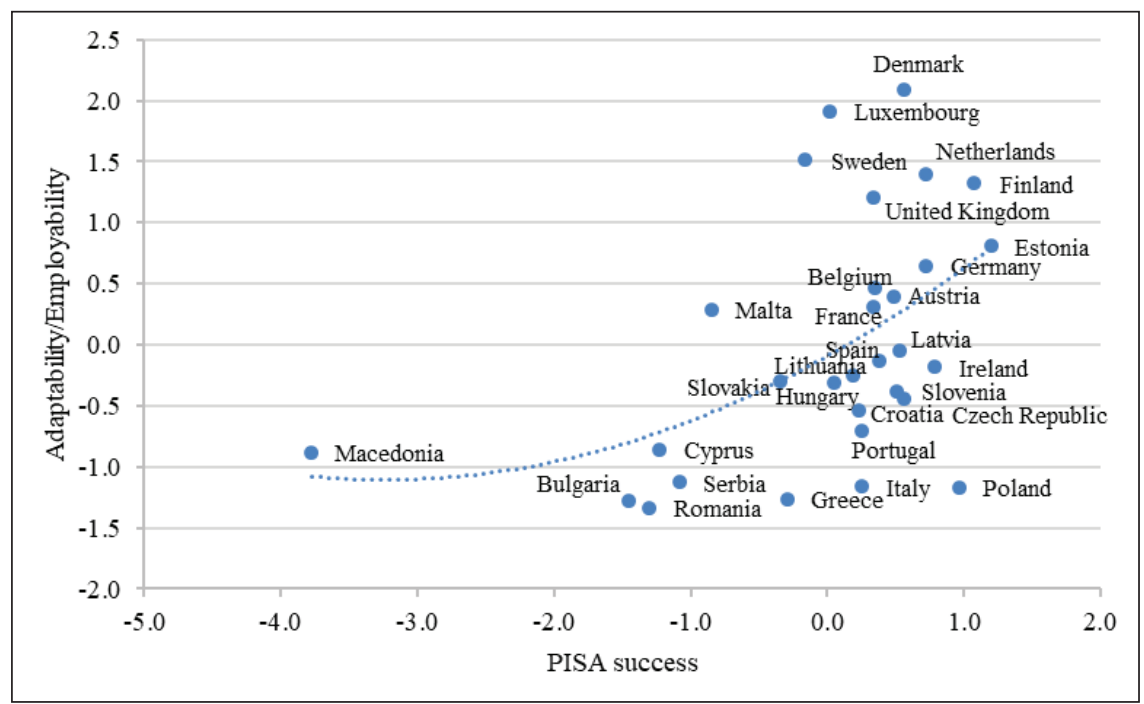

Source: Authors' calculations

Distribution of countries indicates that in terms of adaptability/employability, the lowest ranking countries are Romania, Bulgaria and Greece, while the best performing are Denmark, Luxembourg and Sweden. With regards to the mentioned elements of PISA score, the top ranking ones are Finland, Estonia and Poland, while the lowest ranked being Macedonia, Bulgaria and Romania. The scatterplot (Figure 1) also indicates positive relationship between adaptability/employability and PISA results. For the PISA test results, Macedonia is identified as an outlier, which may be at least partly explained by the fact that PISA 2015 was the first PISA wave in that country. Therefore, after dropping the outlier, the cluster analysis is conducted (Table 3 ).

Table 3: Cluster analysis results

\begin{tabular}{|l|l|l|}
\hline & Performance & \multicolumn{1}{|c|}{ Countries } \\
\hline Cluster 1 & Low & Bulgaria, Cyprus, Greece, Romania and Serbia \\
\hline Cluster 2 & Medium & $\begin{array}{l}\text { Austria, Belgium, Croatia, Czech Republic, France, Hungary, Ireland, } \\
\text { Italy, Latvia, Lithuania, Malta, Poland, Portugal, Slovakia, Slovenia } \\
\text { and Spain }\end{array}$ \\
\hline Cluster 3 & High & $\begin{array}{l}\text { Denmark, Estonia, Finland, Germany, Luxembourg, Netherlands, } \\
\text { Sweden and United Kingdom }\end{array}$ \\
\hline
\end{tabular}

Source: Authors' calculations

$\overline{8}$ If Macedonia were included into analysis, it would belong to Cluster 1, and the position of Greece would change to Cluster 2. 
Cluster 3 has the best performances in terms of all selected variables, while the Cluster 2 outperforms Cluster 1 in all observed variables, at the same time performing worse than the Cluster 3 . Results are also relatively stable when the $\mathrm{K}$-means clustering is performed on the results of PCA instead on the original variables - in this case only Belgium moves the best-performing cluster group, and Malta changes cluster membership to the low performing group. The results suggest that the lowest-performing cluster consists of the South and South-eastern European countries, while the Central Europe, Baltics and some Western Europe countries belong to the medium-performing cluster. The best performing cluster consists mostly of the North and Western European countries.

To overcome the shortcomings of the K-means clustering method (i.e. problems with sensitivity to outliers, concerns about stability of clusters and sensitivity to the order in which data is assembled), we also use Latent Class Cluster Analysis (LCCA). The main difference between LCCA and traditional cluster analysis is linked to the fact that LCCA is model-based and cluster analysis is not (Schreiber, 2017). In LCCA, it is assumed that there is a nominal latent variable with $n$ categories which are called clusters or classes. LCCA classifies cases into unobserved subpopulations represented by a categorical latent variable which is not observed and must be inferred form the data (i.e. from the indicator variables ${ }^{9}$ ) (Pei et al, 2017). This is done on the basis of membership probabilities estimated directly from the model. The most popular model-based approach is known as mixture-model clustering, where each latent class represents a hidden cluster (Magidson, 2005). The optimal subgroup structure that explains the most variance is determined while requiring the simplest specification of the model (Kent et al, 2014).

The models with different numbers of classes are compared using information criteria (IC)-based fit statistics such as Consistent Akaike Information Criteria (CAIC), Bayesian Information Criteria (BIC) and AIC3 (Akaike information criterion with 3 as penalizing factor), where lower values of these criteria indicate a better model fit. While the K-means method itself provides no information about the optimal number of clusters and therefore involves arbitrary selection, LCCA gives various diagnostics, which can be useful in determining the number of clusters. In that way, the decision to adopt a particular model is less subjective. Another important advantage of LCCA lies in the fact that the items do not need to have the same scale or equal variances (Schreiber, 2017). Beside larger classification accuracy, there are also other advantages of LCCA over traditional clustering methods, like better handling missing data problem and provision of classification probabilities for each case. To determine the most optimal number of classes, we

\footnotetext{
$\overline{9}$ Indicator variables used to determine latent classes can be continuous, binary, ordered/unordered categorical counts, or combinations of these variable types (Pei et al., 2017).
} 
used IC indices. An initial run of 1-6 clusters was analyzed, and, in accordance with BIC (Bayes Information Criterion), AIC3 and CAIC, the model with 3 clusters was chose ${ }^{10}$. All three indices consistently showed that the three-class model provides significantly better fit, with the lowest values of BIC, AIC3 and CAIC. The results of the LCCA are presented in Figure 2 and Table 4.

Figure 2: Cluster means

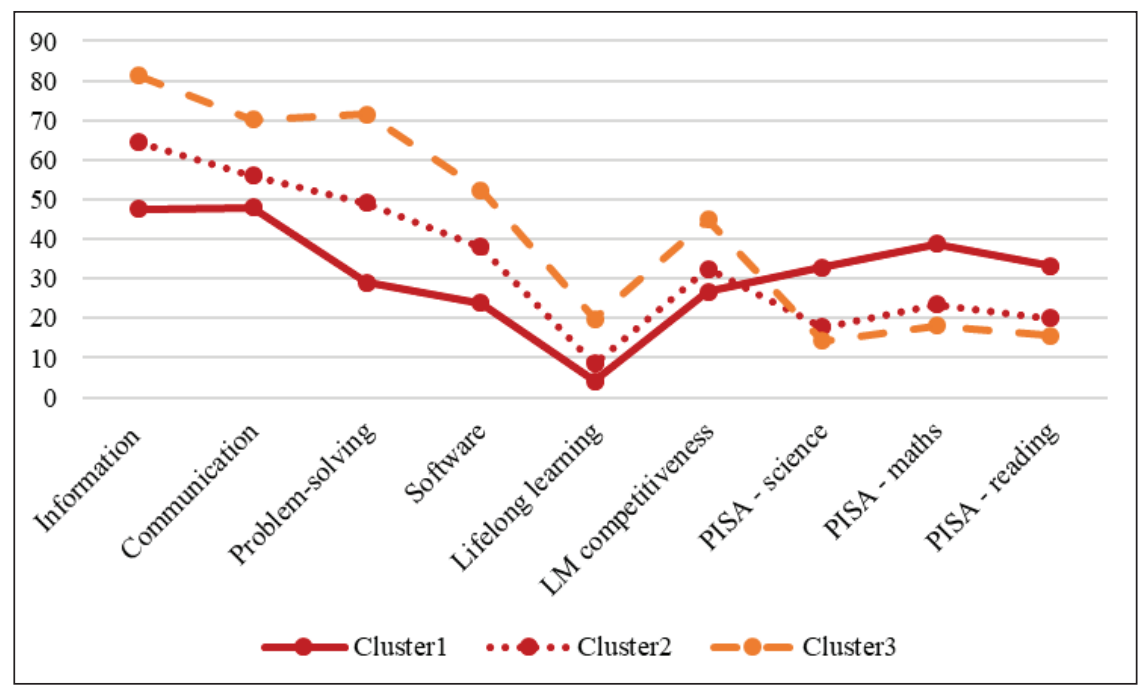

Source: Authors' calculations

The Figure 2 shows the means of all indicators across three latent clusters. It is important to notice that PISA results are given as percentages of underachievers so that the larger values here point to the worse results. Cluster 1 has the lowest mean values for all adaptability/employability indicators (as defined in PCA): participation in lifelong learning, perception of employability and above basic digital competences (information, communication, software and problemsolving skills), while the percentages of the underachieving students in reading, mathematics and science in PISA testing are the highest in this cluster. Cluster 2 has better results in comparison to Cluster 1 in all domains, while Cluster 3 outperforms both Cluster 2 and Cluster 1.

\footnotetext{
${ }^{10}$ It is assumed that for LCA models BIC is a good indicator for deciding which model to choose (Schreiber, 2017; Nylund et al, 2007).
} 
Maja Jandrić, Saša Ranđelović • Adaptability of the workforce in Europe - changing skills...

Table 4: Latent class cluster analysis results

\begin{tabular}{|c|c|l|}
\hline & Performance & \multicolumn{1}{|c|}{ Countries } \\
\hline Cluster 1 & Low & $\begin{array}{l}\text { Bulgaria, Greece, Romania, Serbia, Macedonia, Italy, Portugal and } \\
\text { Poland }\end{array}$ \\
\hline Cluster 2 & Medium & $\begin{array}{l}\text { Austria, Belgium, Croatia, Czech Republic, France, Hungary, Ireland, } \\
\text { Latvia, Lithuania, Malta, Slovakia, Slovenia, Spain and Cyprus }\end{array}$ \\
\hline Cluster 3 & High & $\begin{array}{l}\text { Denmark, Estonia, Finland, Germany, Luxembourg, Netherlands, } \\
\text { Sweden and United Kingdom }\end{array}$ \\
\hline
\end{tabular}

Source: Authors' calculations

Countries' positions according to cluster groups are shown in Table 4. The best performing cluster is stable - it is the same as when K-means method was used. In comparison to the results based on K-means method, only Italy, Poland, Portugal and Cyprus have changed the cluster groups. Cyprus has moved from Cluster 1 to Cluster 2, while Italy, Poland and Portugal have moved from the Cluster 2 to Cluster 1, although some of these countries perform well in terms of PISA results (e.g. Poland). Other countries have remained in the same cluster, which indicates the robustness of clustering under different methods (see Figure 3).

Figure 3: Distribution of countries and clustering

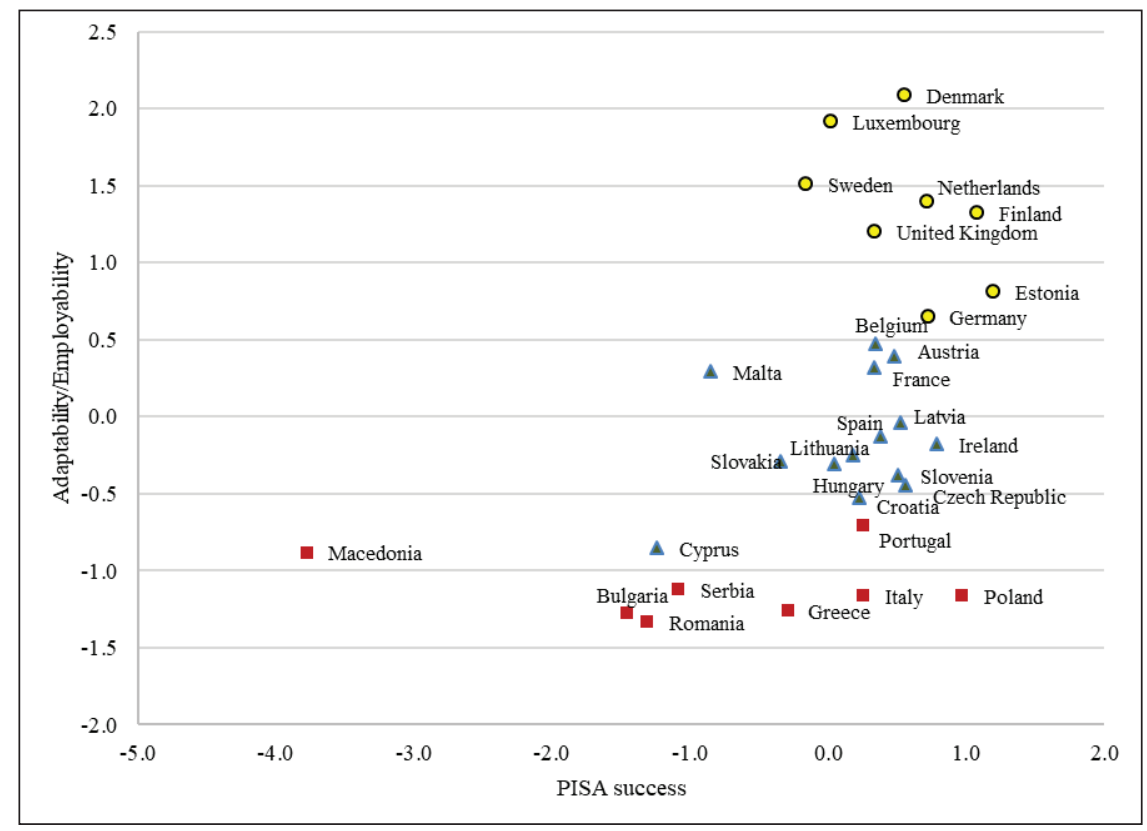

Source: Authors' calculations 
Results from the two methodological approaches have been presented at the Figure 3, axes and country positions being based on PCA, while symbols represent results from the $\mathrm{LCCA}^{11}$. The results of LCCA are in line with the interpretation of country positions based on PCA results. The other important point is that the cluster groupings are relatively stable and very similar to the ones obtained by the $\mathrm{K}$-means method of clustering. The best performing countries are good both in adaptability/employability scores and PISA success. Medium performing cluster is relatively similar to the best performing one in the terms of PISA success, while it lags behind in terms of adaptability and employability. The low performing cluster has the lowest performance in terms of adaptability/employability, while in terms of the PISA score, that cluster can be divided into two groups: countries with relatively good PISA results (Poland, Portugal and Italy), and countries with weak PISA results (Macedonia, Bulgaria, Romania, Serbia and Greece). This means that some of the countries from the low performing cluster could move to the medium performing cluster, by focusing their reform efforts primarily to development of skills required for the workforce adaptability, while the remaining countries from the low performing cluster would need to put efforts both on improvement of PISA scores and adaptability, in order to migrate to the medium performing cluster.

\section{Results and discussion}

PCA has revealed two factors that explain $85.4 \%$ of variability in the original data, thus indicating that there are two main dimensions of the workforce adaptability potential: the PISA score, and the set of properties, encompassing different aspects of digital skills, participation in lifelong learning programs and the perception of the probability for finding a new job in the near future.

In order to mitigate the methodological shortcomings of the K-means method and to check the robustness of the results, the LCCA has been applied. Both K-means cluster analysis and the LCCA suggest that with regards to the workforce adaptability and capacity to face rapid technological changes, the best performers are Northern and Western European countries: Denmark, Estonia, Finland, Germany, Luxembourg, Netherlands, Sweden and United Kingdom. In the other side of the spectrum, according to both methods applied, are the low performing countries, mostly from South and South-eastern Europe, such as: Bulgaria, Greece, Romania, Serbia and Macedonia, while according to LCCA Portugal, Italy and Poland also belong to the low performing cluster. However, this cluster is to an extent heterogeneous, as some of these countries (Bulgaria, Romania, Serbia, Macedonia and to some extent Greece) are lagging behind both in terms of PISA success and adaptability/employability,

${ }^{11}$ Circles - best performing cluster; Triangles: medium performing cluster, Squares: low performing cluster. 
while the remaining countries (Portugal, Italy and Poland) are lagging behind only in terms of adaptability/employability, while performing well in terms of PISA scores.

Between the high and low performing clusters are several countries with solid performances both in terms of PISA scores and adaptability/employability. This medium performing cluster includes a variety of countries from Central, Western and South Europe, as well from the Baltics, such as: Austria, Belgium, France, Malta, Spain, Latvia, Lithuania, Ireland, Slovakia, Hungary, Slovenia, Czech Republic and Croatia.

The countries that belong to the low performing cluster have at the same time relatively low employment and activity rates, which raises concerns about deepening future structural problems. Namely, if this trend is not reversed, policies aimed at fostering growth through adoption of new technologies would not be accompanied with compatible level of the workforce skills, thus imposing effective limitation to growth. Even in occupations that are not directly influenced by technological change, the nature of work changes and still requires adoption of new knowledge and skills. Although there is a thesis that "a creation of skill-intensive job with complex tasks provides opportunities to acquire skills continuously, i.e. good jobs lead to better skills" (Cedefop, 2015: 8.), a certain level of initial labor force adaptability is necessary to initiate this process.

It may also be important to note that country clustering based on the workforce adaptability is rather similar to the grouping which could be done based on the level of economic and social development of sample countries. This may indicate that there is an interlink between the level of development and skills adaptability. However, further research is needed to confirm a causal relationship. Hanushek and Woessmann (2008) find evidence on the strong relationship between cognitive skills and economic outcomes, which is remarkably robust. They also state that the existing evidence suggests that cognitive skills independently affect economic outcomes even after controlling for other factors and that "although it is difficult to establish conclusively that this is a causal relationship, the robustness of the result lends considerable credence to such an interpretation". However, in our case, to make conclusion on the relationship between adaptability and economic development, additional empirical evaluation would need to be done, which is beyond the focus of this paper.

\section{Conclusion}

Contemporary labor markets are exposed to rapid demographical and technological changes. The ability of the workforce to make the necessary adjustments to the set of needed knowledge and skills is one of the important factors that determine in what way will particular country's labor market react to technological changes. 
Effects of these changes can be divided into two broad groups: (1) creation of the new jobs and destruction of the existing ones under the influence of automation and robotization and (2) application of new technologies in the cases when jobs are not susceptible to technology substitution, that lead to changes in organization and the nature of work. Both aspects lead to significant changes related to the knowledge and skills needed in the labor market, which points out the importance of constant improvement of the workforce's competences. Our results confirm that the initial set of 9 indicators of the workforce adaptability can be reduced to two dimensions: adaptability/employability and PISA success. According to analysis based on large set of indicators, although there is a large variation across 30 European countries, these countries can be pooled into three clusters, based on the adaptability and employability of their workforce, as well as on their functional knowledge in reading, mathematics and science, which confirms our second hypothesis. Northern European and a number of Western European countries have been identified as the best performing countries in terms of adaptability, employability and the functional knowledge. On the other side of the spectrum are countries from South and South-eastern Europe, which generally have very low levels of adaptability of the workforce. Although general improvements in education system are essential and especially important in the medium and long run, our findings suggest that there is no single optimal policy that would fit all countries. Instead, a policy mix, aimed at boosting performances of the labor market should be tailor made to the specific country features. In that respect, some countries can make significant progress and migrate to higher cluster, by mostly focusing on improvement of the workforce adaptability (e.g. Belgium, Austria, France, Ireland, Poland), while the other low and medium performing countries need to act simultaneously in improving both their PISA performances and skills that shape workforce adaptability. In that respect, a wide set of policy measures would need to be activated, including general improvement of education and functional literacy, improvement of system of informal education, redesign and reinforcement of the active labor market policies, increasing incentives for both employers and employed persons to take part in training programs, to adopt life-long learning approach. Identifying and anticipating skill shortages and mismatches and providing a better link between labor market needs and educational and training system are also an important part of a policy-mix. Some studies also underpin the importance of employment stability for promoting investment in skill development (Cedefop, 2015), especially with regard to firm-specific skills. Evaluating impact of different labor market institutions on the workforce adaptability is an important field that requires a more detailed research. Future research, based on new data, could show whether there is improvement in selected countries and what aspects of the workforce adaptability require more action. Identification of benchmarks and optimal development paths could also be one of the avenues for the future research, which would also provide important input for policy/makers. 


\section{References}

Aaker, D.A., Kumar, V., Day, G. (2008) Marketinško istraživanje, Beograd: Ekonomski fakultet.

Bejaković, P., Mrnjavac, Ž. (2014) "Skill mismatches and anticipation of the future labour market need: Case of Croatia", Zagreb international review of economics \& business, Vol. 17, No. 1, pp. 47-68.

Brown, P., Hesketh, A., Wiliams, S. (2003) "Employability in a Knowledge-driven Economy", Journal of Education and Work, Vol. 16, No. 2, pp. 107-126, doi: 10.1080/1363908032000070648.

Boeri, T., Garibaldi, P., Macis, M., Maggioni, M. (2002) "Adaptability of labour markets: a tentative definition and a synthetic indicator", Fondazione Rodolfo Debenedetti. Available at: <http://www.frdb.org/be/file/_scheda/files/ada2002. pdf $>$, [Accessed: March 5, 2018].

Cunningham, W., Villaseñor, P. (2016) "Employer Voices, Employer Demands, and Implications for Public Skills Development Policy Connecting the Labor and Education Sectors", Policy Research Working Papers, doi: 10.1596/1813-94507582.

Degryse, C. (2016) "Digitalisation of the Economy and its Impact on Labour Markets”, SSRN Electronic Journal, doi: 10.2139/ssrn.2730550.

Dimian, G.C., Begu, L. S., Jablonsky, J. (2017) "Unemployment and labour market mismatch in the European Union Countries", Zbornik radova Ekonomskog fakulteta u Rijeci: časopis za ekonomsku teoriju i praksu, Vol. 35, No. 1, pp. 13-44, doi: 10.18045/zbefri.2017.1.13.

European Centre for the Development of Vocational Training (CEDEFOP). (2015) "Matching skills and jobs in Europe: insights from Cedefop's European Skills and Jobs survey", Available at: <http://www.cedefop.europa.eu/files/8088_en. pdf $>$, [Accessed: March 15, 2018].

Frey, C. B., Osborne, M. A. (2017) "The future of employment: how susceptible are jobs to computerisation?", Technological Forecasting and Social Change, Vol. 114, pp. 254-280, doi: 10.1016/j.techfore.2016.08.019.

Grossman, G. D., Nickerson, D. M., Freeman, M. C. (1991) "Principal Component Analyses of Assemblage Structure Data: Utility of Tests Based on Eigenvalues", Ecology, Vol. 72, No. 1, pp. 341-347, doi: 10.2307/1938927.

Eshet-Alkalai, Y. (2004) "Digital Literacy: A Conceptual Framework for Survival Skills in the Digital era", Journal of Educational Multimedia and Hypermedia, Vol. 13, No. 1, pp. 93-106. Available at: $<$ https://www.openu.ac.il/personal sites/download/Digital-literacy2004-JEMH.pdf>, [Accessed: November 20, 2018].

European Commission. (2009) Communication from the Commission to the European Parliament, the Council, the European Economic and Social Committee 
and the Committee of the Regions: "Key Competences for a changing world", $\operatorname{COM}(2009)$ 640., Available at: https://eur-lex.europa.eu/legal-content/ga/ TXT/?uri=CELEX:52009DC0640, [Accessed: November 19, 2018].

Hanushek, E. A., Woessmann, L. (2008) "The Role of Cognitive Skills in Economic Development", Journal of Economic Literature, Vol. 46, No. 3, pp. 607-668, doi: $10.1257 /$ jel.46.3.607.

Kent, P., Jensen, K., Kongsted, A. (2014) "A comparison of three clustering methods for finding subgroups in MRI, SMS or clinical data: SPSS TwoStep Cluster analysis, Latent Gold and SNOB", BMC medical research methodology, Vol. 14, No 1, pp. 2-14, doi: 10.1186/1471-2288-14-113.

Magidson J., Vermunt J.K. (2005) "A nontechnical introduction to latent class models", Available at: < https://www.statisticalinnovations.com/wp-content/ uploads/Magidson2002.pdf>, [Accessed: March 22, 2018].

Manyika, J. et al. (2017) "A future that works: Automation, employment, and productivity”, New York: McKinsey Global Institute.

Nylund, K. L., Asparouhov, T., Muthen. B. (2007) "Deciding on the number of classes in latent class analysis and growth mixture modelling: A Monte Carlo simulation study", Structural equation modelling, Vol. 14, No. 4, pp. 535-569, doi: 10.1080/10705510701575396.

OECD (2008) Handbook on constructing composite indicators: Methodology and user guide, Paris: Joint Research Centre-European Commission. OECD publishing, doi: 10.1787/9789264043466-en.

Pei, L. et al. (2017) "Using latent class cluster analysis to screen high risk clusters of birth defects between 2009 and 2013 in Northwest China", Scientific reports, Vol. 7, No. 1, doi: 10.1038/s41598-017-07076-0.

Peres-Neto, P. R., Jackson, D. A., Somers, K. M. (2003) "Giving meaningful interpretation to ordination axes: assessing loading signifiance in principal component analysis", Ecology, Vol. 84, No. 9, pp. 2347-2363, doi: 10.1890/000634 .

Rodrik, D. (2016) "Premature deindustrialisation", Journal of Economic Growth, Vol. 21, No 1, pp. 1-33, doi: 10.3386/w20935.

Sheperd, J. (2004) "Why the Digital Era". In Doukidis, G., Mylonopoulos, N., Pouloud, N. (eds.), Social and Economic Transformation in the Digital Era, pp. 1-18. London: Idea Group Publishing, doi: 10.4018/978-1-59140-158-2U.

Schreiber, J. B. (2017) "Latent Class Analysis: An example for reporting results", Research in Social and Administrative Pharmacy, Vol. 13, No. 6, pp. 1196-1201, doi: 10.1016/j.sapharm.2016.11.011.

Tinsley, D., Monastiriotis, V. (2007) "Developing an Index of Labour Market Adaptability for the UK", DTI Employment Relations Research Series No. 85. London: Department of Trade and Industry UK. 
World Bank (2016) World Development Report 2016: Digital Dividends, Washington, DC: The World Bank, doi: 10.1596/978-1-4648-0671-1. (2018) World Development Report 2019: The Changing Nature of Work, Washington, DC: The World Bank, doi: 10.1596/978-1-4648-1328-3.

\title{
Prilagodljivost radne snage u Europi - promjene vještina u digitalnoj eri
}

\author{
Maja Jandrić ${ }^{1}$ Saša Ranđelović ${ }^{2}$
}

\begin{abstract}
Sažetak
Digitalne tehnologije značajno utječu na tržište rada, pri čemu mogu biti komplementarne s radom ili ga supstituirati. To je potaknulo promjenu u skupu vještina koje se traže na tržištu rada. Sve veći značaj dobivaju vještine vezane za rješavanje problema, kreativnost, socio-emocionalne vještine, kao i funkcionalnu pismenost $i$ tehničke vještine vezane za korištenje digitalnih tehnologija. Utjecaj digitalizacije na tržište rada i ekonomske performanse pojedinih zemalja ovise o prilagodljivosti radne snage, industrijskoj strukturi, strukturi zaposlenosti prema zanimanjima, o skupu znanja i vještina koje posjeduje radna snaga, organizaciji rada i trenutnom stupnju primjene digitalne tehnologije. Cilj ovog rada je ocijeniti stupanj prilagodljivosti vještina radne snage u 30 europskih zemalja, koristeći podatke OECD-a o postignućima u čitanju, matematici i prirodnim znanostima, kao i podatke o digitalnim kompetencijama, uključivanju u cjeloživotno učenje $i$ subjektivnoj percepciji sposobnosti pronalaska novog posla. Naši rezultati sugeriraju pozitivan odnos između prilagodljivosti i PISA rezultata. Korištenjem analize glavnih komponenti, klaster analize i LCCA (latent class cluster analysis), možemo zaključiti da se europske zemlje mogu grupirati u tri klastera u smislu prilagodljivosti: klaster visokih performansi (Sjeverna i Zapadna Europa), klaster srednje uspješnih zemalja (Srednja Europa i baltičke zemlje) i klaster zemalja sa slabim performansama (Južna i Jugoistočna Europa). Za neke zemlje, niske razine prilagodljivosti radne snage mogu predstavljati važnu prepreku za budući rast $i$ razvoj.
\end{abstract}

Ključne riječi: tržište rada, digitalizacija, cjeloživotno učenje, digitalne kompetencije, analiza glavnih komponenti, klaster analiza na osnovu klase latentnih modela

JEL klasifikacija: J21, J24, J62

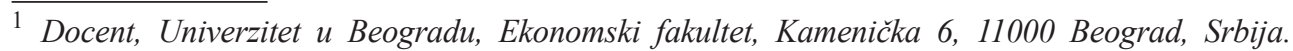
Znanstveni interes: ekonomska teorija i analiza-makroekonomija. Tel.: +381113021184, E-mail: maja@ekof.bg.ac.rs.Web stranica: http://www.ekof.bg.ac.rs/maja-jandric-phd/?lang=en (osoba za kontakt).

${ }^{2}$ Izvanredni profesor, Univerzitet u Beogradu, Ekonomski fakultet, Kamenička 6, 11000 Beograd, Srbija. Znanstveni interes: ekonomska teorija i analiza - makroekonomija. Tel.: +381113021183,E-mail: randjelovic@ekof.bg.ac.rs. Website: http://www.ekof.bg.ac.rs/sasarandjelovic-phd/?lang=en. 


\section{Appendices}

Table A1: Skills in Digital Competence Framework

\begin{tabular}{|l|l|}
\hline \multicolumn{1}{|c|}{ Skills } & \multicolumn{1}{|c|}{ Definition in Digital Competence Framework } \\
\hline Information skills & $\begin{array}{l}\text { Identify, locate, retrieve, store, organise and analyse digital } \\
\text { information, judging its relevance and purpose. }\end{array}$ \\
\hline Communication skills & $\begin{array}{l}\text { Communicate in digital environments, share resources } \\
\text { through online tools, link with others and collaborate through } \\
\text { digital tools, interact with and participate in communities and } \\
\text { networks, cross-cultural awareness. }\end{array}$ \\
\hline Problem solving skills & $\begin{array}{l}\text { Identify digital needs and resources, make informed decisions } \\
\text { as to which are the most appropriate digital tools according to } \\
\text { the purpose or need, solve conceptual problems through digital } \\
\text { means, creatively use technologies, solve technical problems, } \\
\text { update one's own and others' competences. }\end{array}$ \\
\hline Software skills & $\begin{array}{l}\text { Create and edit new content (from word processing to images } \\
\text { and video); integrate and re-elaborate previous knowledge } \\
\text { and content; produce creative expressions, media outputs and } \\
\text { programming; deal with and apply intellectual property rights } \\
\text { and licences }\end{array}$ \\
\hline
\end{tabular}

Source: http://ec.europa.eu/eurostat/cache/metadata/en/tepsr_sp410_esmsip.htm

Table A2: KMO and Bartlett's Test

\begin{tabular}{|l|l|r|}
\hline Kaiser-Meyer-Olkin Measure of Sampling Adequacy. & .822 \\
\hline Bartlett's Test of Sphericity & Approx. Chi-Square & 357.373 \\
\cline { 2 - 3 } & df & 36 \\
\cline { 2 - 3 } & Sig. & .000 \\
\hline
\end{tabular}

Source: Authors`calculations 